\title{
Utilizing learning theories in the digital age: from theory to practice
}

\author{
Dean Giustini
}

\section{Key messages}

(1) By drawing on a basic understanding of adult learning theory and instructional design principles, health librarians can develop even more successful, learner-centred library programs

(2) Some useful starting points in designing health library workshops include $(i)$ gathering information about your learners; (ii) examining their preferred learning styles; and, most importantly, (iii) considering their context and professional practice

(3) To find your own starting point in developing health library workshops, consider structured approaches such as Sork's planning model or Young and Harmony's "how-to" framework

(4) The University of British Columbia's Centre for Teaching and Academic Growth (TAG) provides further ideas for the design of instructional sessions using the "BOPPPS model"

\section{Introduction}

This is the second column in the JCHLA / JABSC series about teaching and learning in health libraries. In the first column, I introduced health librarians to the major learning theories in educational planning and hinted at their application in instructional design [1].

In column 2, I focus on the practical elements of library workshop design, one of the five teaching skills identified as starting points in my first column. Throughout this discussion I am asking some straightforward but persistent questions about teaching in academic health and hospital contexts. Given the rise of Web 2.0 tools and evidence-based practice, how can health librarians design more learnercentred, interactive workshops? What principles of instructional design are applicable to the classroom to ensure that library teaching is relevant, grounded theoretically, and ultimately successful in imparting new skills?

In the digital age, library teaching requires a deeper level of understanding of the motivations, needs, and search habits of our learners. To accommodate them, teachers can now select from more than 50 learning theories [2], with newer digital theories such as connectivism gaining in popularity [3].
As stated in column 1, how we teach may be as important as what we teach in the digital age. Since many new library users are tech-savvy and grow up "digital", they bring a certain set of pedagogical challenges to library workshopsand we should try to meet them [4].

The three major adult learning theories that have been discussed so far-behaviourism, constructivism/cognitivism, and situated-learning (see Table A1 in Appendix A)-illustrate a wide range of learning theories available to the health librarian. While representing just the tip of the iceberg, these major theories should be seen as the foundation for further analysis and study. Over time, understanding can be deepened by evaluating these theories rigorously within the context of our users' learning needs and professional practice.

\section{Workshop design has its own theory}

Adult educators have spent the last fifty years trying to develop more sophisticated approaches to [workshop] planning. It is time that we shifted focus from finding the perfect planning model to asking the right questions [5].

One of the recurring questions in academic librarianship is how to transfer pedagogical knowledge to the classroom. In health librarianship, many of us know what our end-users want to learn when attending library workshops and plan accordingly. In doing so, we draw on our previous teaching experiences and integrate best practices from colleagues and the literature. Throughout the iterative process of building teaching skills, we are engaged in continuous improvement by asking relevant questions about our learners.

However, like patient-centred care, putting the learner at the centre of the teaching enterprise requires a paradigm shift. How many of us have looked at this in detail? Our intuitive sense of what our end-users need is invariably led by technological developments. Why? Because monitoring changes to CINAHL and MEDLINE and the latest features in tools such as PubMed and Google Scholar is central to our work (see a sample plan in Table A2 in Appendix A). However, while this approach has proven successful (enough) in the past, it does not account for the full challenge of designing learner-centred teaching programs in the $21 \mathrm{st}$ century [6]. Intuitive teaching and show-and-tell pedagogies are only adequate to a point. 
Simply put, as teachers, how do we build on what we want our users to know? First, finding a systematic process for designing workshops, based on a sound analysis of learner needs, is a necessity. Ultimately, teaching will be far more durable and successful if we can ground it theoretically.

Two prominent names in designing learner-centred workshops are Sork [7-10] and Caffarella [11]. If you are inclined to study this topic in some depth, I recommend Sork's planning model (for a hybrid model I developed, see Figure A1 in Appendix A) and a recent narrative review written by Kenny et al. [12]. Furthermore, Jerilyn Veldof, an American academic librarian, has written a book entitled Creating the one-shot library workshop: a step by step guide (see also Veldof's blog) [13].

\section{Understanding the context for learning}

A basic principle of teaching adults is that each learner has extensive life experience to draw upon which allows open dialogue with instructor...based on his or her experience, the acquisition of new skills, knowledge and abilities will be in relation to the [learners'] experience levels... [14].

Savvy health librarians understand that teaching programs are potent current awareness tools and will exploit every possible "teachable moment" to market the library, its programs, and services. Increasingly, teaching is used to promote the library's central place in the evidence-based culture of health organizations. Any opportunity, therefore, to increase our visibility and market the library should be seized.

Before you begin to design your library workshops for optimal visibility and learning, consider examining your learner community. Who are they and what do they do? Are they practitioners or researchers? Have they attained basic information skills? Are they able to search PubMed, CINAHL, and the Cochrane Library efficiently?

Whether you are a solo health librarian working in a large organization or part of a larger team of librarians, devising a set of strategies to gather information about your learners will be important. One library monograph I found helpful in this regard was Young and Harmony's Working with faculty to design undergraduate information literacy programs: a how-to-do-it manual for librarians [15]. It offers a number of key points in gathering information for your teaching and related "one-off" classes and workshops.

Simply put, a number of possibilities arise from a reading of Young and Harmony's how-to manual:

(1) Do a needs-assessment - Health professionals need to attend a library workshop often because they need to learn information skills for their work. Be sure to consider the immediate and long-term needs of your users by conducting a needs assessment or survey. Are your sessions (or lectures) standalone or are they part of a series of workshops and seminars in a program? Perhaps you are interested in developing an entire course on information literacy or integrating your sessions with academic health programs, residencies, and directed studies.

(2) Create teaching partnerships - Health librarians understand that trust is critical in building relationships with their user groups. After you meet each other, ask them what teaching partnerships are already in place. Can you collaborate with your constituents (i.e., hospital educators, faculty, and staff) to integrate your teaching more directly into existing educational programs? Can the library's teaching be a part of the ongoing medical education or research within your organization?

(3) Build your own teaching competencies - Good teaching has a long list of competencies; in one study, there are more than 80 in total [16]. However, two-way dialogue and exchange between teachers and learners is a musthave skill. You must be able to talk to your users and engage them directly using enquiry-based methods. Build your competencies by getting feedback from trusted colleagues. Some pedagogical strategies are more effective than others so consider working with a mentor or peer in your organization to share and exchange ideas.

(4) Assess the political and technological climate - What policies, scheduling issues, classroom needs, or instructional materials do you require as you begin your planning? Do you have limitations in terms of teaching spaces and (or) technology (e.g., firewalls) in your organization? How will a lack of suitable space have an impact on learning in teams?

These four areas can be grouped as teaching-related (requiring certain skills or competencies) or strategic (understanding organizational and political contexts) [17]. Health librarians will want to consider these key issues as they embark on the development or redesign of their teaching programs.

Finally, before you begin the design of any instructional program, determine whether an environmental scan of the various kinds of educational activities has actually already taken place within your organization. Adult learners in health tend to be task-centered and problem-based. Have you spoken to the relevant educators in medicine, nursing, and pharmacy about your plans? Have their learning needs been taken into account and identified in a strategic plan? Were any follow-up surveys done to determine whether these learning needs were met?

\section{Planning overall design process}

The ultimate goal of teaching is to foster critical thinking and skills-acquisition - even to bring about a change in attitudes. However, the development of library workshops requires an attention to sound planning, particularly the information-gathering and evaluation aspects of instructional design.

\section{Design of health library workshops and course-integrated teaching}

First, develop a profile or matrix of your users. What characteristics of your planning and learner community are especially important for you to know? There are numerous issues to consider such as the number of learners, their practice habits, and existing knowledge/skills. Further, what information literacy objectives do they want to achieve? You may want to consider how each of these factors will affect the design and delivery of your program. 
Consider the larger philosophical and pedagogical issues that form the background of your teaching. Most successful teaching programs these days provide intellectual stimulation and personalization ("teach to the project or assignment"). Can you motivate your diverse learners? What fun or memorable learning exercises can you use in class? Effective curriculum design these days also begins with a list of learning outcomes. This type of preparation can be included in a workshop's goals and objectives as you move forward.

As mentioned in the first column, our teaching should always be grounded theoretically somehow. However, remember that a blended-approach of theory and practice is likely to be most successful. You do not need to be prescriptive with yourself or seek a one-size-fits-all solution for your classes. Even a basic understanding of hybrid approaches will help you to find appropriate activities for each group. This should not be an overly intellectual process; when in doubt, involve your learners in the workshop design and solicit feedback.

It may be important to consider what kinds of dominant learning styles exist in your class. Do nurses prefer social learning? Medical students-do they enjoy competitive activities? Health librarians are accustomed to doing this kind of research before they develop their curriculum and are encouraged to build those skills further.

Finally, health librarians should align their goals and objectives for the workshop with the activities that are being planned. Giving participants enough free time to try out new technologies - allowing them to see why a new database or e-resource is worth learning-makes it possible for them to consider how they might integrate these tools into their practice. In your design, give your learners options to learn things on their own and suggest that they can decide what will work best for them.

\section{Delivery of your workshop: the four "Ps" of performing}

(1) Preparation for the workshop - The actual delivery of workshops and short courses involves considerable preparation. You work with your group's contact person, ask relevant questions, master the content to be taught, analyze the learners' environment, anticipate technical problems with facilities or equipment, and create or revise teaching materials as needed. Obviously, any health librarian presenting will want to allot time for mental preparation before the workshop.

(2) Presentation of the workshop - Some librarians speaking at conferences or during hospital rounds rehearse with a trusted colleague who can provide feedback. Any presentation requires a certain amount of rehearsal, but working toward conceptual clarity, effective content development, appropriate design, and use of presentation media and materials will help considerably.

(3) Pace of the workshop - Finding the right pace, rhythm, and openness are among the many challenges for presenters. For example, if you use more social learning approaches, how can you stay on time with your content? Effective pacing requires a keen sensitivity to the needs of your audience, their time limitations, individ- ual needs and schedules, self-confidence, self-control, and timing.

(4) Pitch used in workshop - Any opportunity to talk to health professionals about library services implies marketing and outreach. Health librarians will want to raise their awareness of the audience to a sufficient degree that they are using language that is universally understood. Avoid library jargon and other technical terms or explain them clearly. By designing appropriate learning experiences for specific groups, you have a greater opportunity to select appropriate resource materials and implement suitable strategies to facilitate audience management and interaction.

\section{Evaluation of teaching and information literacy programs}

Not surprisingly, the success of any teaching or information literacy program may hinge on rigorous feedback from users. Evaluation of courses, seminars, and workshops is often seen as a way for health librarians to "close the loop" on their sessions. Reviews by participants are critical in terms of providing positive and helpful feedback, but peer review or the use of videotaping may also be useful in appraising performance. Health librarians may want to select and develop appropriate rubrics or algorithms to determine whether the desired learning outcomes have been achieved. It may be necessary to consider novel approaches for evaluation and assessment such as pre-post follow-up, testing, or interviewing.

\section{Individual learning styles}

In column 1 of this series, the issue of learning styles (e.g., visual and auditory, kinesthetic and spatial learning) was discussed. However, another way to look at learning styles is to see them from the perspective of the following five dominant workshop design methods.

(1) Active learning - Will you use an active learning approach in which participants engage more actively in learning and making meaning? In this approach, the instructor assumes the role of facilitator or guide-on-theside. This style is popular in informal learning and may be preferred by those who learn by interacting with peers and instructors. It clearly is linked to constructivist principles.

(2) Computer-assisted instruction (CAI) - In CAI, computers are used to deliver instruction directly to participants in a computer lab or classroom with a subject expert or health librarian facilitating. Interaction is possible but not required. This type of delivery is popular among librarians and used often to teach MEDLINE or PubMed. It may suit those who prefer a "show and tell" or demonstration aspect to learning, particularly as it relates to using databases in professional practice.

(3) Learner-centred instruction - The focus in learnercentred instruction is on individual and group learning needs. Health librarians can determine whether the group's learning needs are heterogeneous by working with leaders beforehand-or by administering a survey before the workshop begins. This pedagogical approach 
can be used for "one to many" classes or "one-to-one" consultations in a librarian's office. One drawback is that this may not be an efficient use of time.

(4) Self-directed, independent learning - The individual learner has primary responsibility for his or her learning. It may involve doing self-pacing tutorials and even group work. This approach is sometimes needed for high achievers or new learners. Health librarians can work with self-directed learners to teach them ever more sophisticated search strategies and sources of information.

(5) Traditional instruction - Instructional material is taught to users by health librarians or search experts. The method is a passive way of learning for students and belongs firmly in the behavioural paradigm.

\section{The BOPPPS model}

Once you create a detailed profile of your learners, consider addressing their learning needs by using an accepted model or framework to design your workshop. Many of the models that are available provide a way to develop the content for your workshop using various pedagogical tips, techniques, and tricks.

At the University of British Columbia, the BOPPPS model is used as a guide for faculty and librarians who want to organize their workshops more effectively [18]. The BOPPPS model stands for the number of steps in the design process: bridge, objective, pre-test, participatory learning, post-test, and summary. This model serves to underscore many basic elements of instruction, such as using ice-breakers or bridging activities, writing statements and objectives, and other techniques to engage learners from the outset.

In more detail, BOPPPS stands for the following:

(i) Bridge - A bridge is an introduction to your workshop. It is a way of generating interest in the class or subject. Various bridging techniques trigger learning and help teachers to gain learners' attention through debate, questions, and stories. Bridges build motivation and help to explain why a topic is important. Short bridgein strategies provide reasons to learn about the topic and tell stories connected with it. Sometimes the bridge-in may refer to a shared experience, a provocative question linked to a current topic, or something else that creates interest.

(ii) Objective - Learning objectives let students know what you're going to teach them and focuses learners and instructors on the purpose of a given lesson. Objectives ensure that everybody understands what is expected and when the learning is accomplished; they establish a foundation for the evaluation of the learning.

(iii) Pre-test - Find out what learners know so you can tailor the class to specific learning needs; pre-tests determine what learners know and allow them to add their experiences to improve participation and engagement as much as possible.

(iv) Pre-assessment strategies - Closed and open questioning can be used to assess the comprehension of a group of learners. Some teachers turn the tables on their learn- ers, asking them to lead the class. Trust is critical for this strategy to be successful.

(v) Participatory learning - Social learning is a common way to invite participation. By encouraging participation and interactivity in the learning process, learners have a chance to direct their own learning. Peer-based models are very effective in health where interdisciplinary teams often work together. Two types of participatory learning are interaction between the instructor and learners, and interaction between the learners themselves. To maintain learners' interest, consider giving them opportunities to lead their own small groups.

(vi) Post-test - Find out how well learners did by giving them a simple test. Administering a post-test provides answers to the following questions: What did the learners learn? Did they meet the stated objectives? What are some of the strategies that are associated with doing a post-assessment; do you give an exam, ask for a presentation or analysis of a scenario? Think of your own examples.

(vii) Summary - Wrap it up, summarize the learning experience, and create a sense of closure. Some of the strategies for closure include content review or feedback of the lecture, acknowledgement of effort, and achievement application. What can they do with the obtained knowledge?

To prepare for teaching, educators typically develop a series of lesson plans that usually contain three main components: an introduction, the delivery of the main content or body of the lecture, and concluding exercises and remarks. The BOPPPS model is an excellent way to begin the process of lesson planning as it provides a rubric for pre-class organization through final wrap-up.

Participatory learning activities are critical in BOPPPS, since they provide opportunities for learners to teach each other. This participatory learning places BOPPPS clearly in the constructivist model or paradigm.

\section{Conclusion}

A recurring theme in adult learning is the idea of finding or locating your learners, i.e., who they are, what they want to learn, and their practice context. As Sork says "planning is influenced by cultural, political and economic factors that influence other social endeavours". By considering the circumstances of who your learners are and how they practice, your focus is contextual-creating learning opportunities that have the greatest impact and chance of success based on skills needed for professional practice.

From theory to practice, health librarians have a range of strategies and models from which to build their teaching programs. Newer approaches to teaching can be grounded in theory and informed by the evidence and experience of other health librarians. Many successful teachers use ongoing reflective techniques adapting their teaching to the changing needs of their learners. In an iterative fashion, health librarians can develop sound strategies to motivate end-users and teach durable, transferable information skills. With so many ways to expand upon our design and delivery of classes in the digital age, we are in the enviable position of discovering 
what works best for our users and modifying our approach accordingly.

In the next column, I will look at some of the newer digital learning theories that may be of interest to health librarians and even explore the possibility of finding new context for some of the standard learning theories already discussed.

\section{References}

1. Giustini D. Utilizing learning theories in the digital age: an introduction for health librarians. J Can Health Libr Assoc. 2008;29:109-15.

2. Kearsley G. Exploration in learning and instruction: the theory into practice (TIP) database [database on the Internet]. c19942008 [accessed 2009 Jan 5]. Available from: http://tip.psychology.org/index.html.

3. Siemens G. Connectivism: a learning theory for the digital age. International Journal of Instructional Technology and Distance Learning. 2005;2(1):3-10.

4. Naslund J, Giustini D. Towards school library 2.0: an introduction to social software tools for teacher-librarians. School Libraries Worldwide. $2008 \mathrm{Jul} ; 13(2)$.

5. Sork TJ. Planning educational programs. In: Wilson AL, Hayes ER, editors. Handbook of Adult and Continuing Education. San Francisco: Jossey-Bass; 2000.

6. UBC Health Library Wiki [wiki on the Internet]. 2007 Sabbatical - Dean Giustini [wiki article] [accessed 5 Jan 2009]. Available from: http://hlwiki.slais.ubc.ca/index.php?title= 2007_Sabbatical_-_Dean_Giustini.

7. Sork TJ. The workshop as a unique instructional format. In: Sork TJ, editor. Designing and implementing effective workshops. New Directions for Continuing Education 22. San Francisco: Jossey-Bass; 1984. p. 3-10.

8. Sork TJ. Mistakes made and lessons learned: Overcoming obstacles to successful program planning. New directions for adult and continuing education: 49. San Francisco: JosseyBass; 1991.

9. Sork TJ. Workshop planning. In: Fleming JA, editor. New perspectives on designing and implementing effective workshops.
New Directions for Adult and Continuing Education 76. San Francisco: Jossey-Bass; 1997. p. 5-17.

10. Sork TJ. Planning educational programs. In: Wilson AL, Hayes ER, editors. Handbook of Adult and Continuing Education. San Francisco: Jossey-Bass; 2000. p. 171-90.

11. Caffarella RS. Planning programs for adult learners: a practical guide for educators, trainers and staff developers. 2nd ed. San Francisco: Jossey-Bass; 2002.

12. Kenny RF, Zhang Z, Schwier RA, Campbell K. A review of what instructional designers do: questions answered and questions not asked. Can J Learn Tech. 2005 Winter;31(1):129. Available from: http://auspace.athabascau.ca:8080/dspace/ handle/2149/390.

13. Veldof J. Creating a one-shot library workshop [weblog for monograph] [accessed 5 Jan 2009]. Available from: http://blog.lib.umn.edu/jveldof/workshopdesign/.

14. Knowles M. The modern practice of adult education: an autobiographical journey. New York: Association Press; 1970.

15. Young R, Harmony S. Working with faculty to design undergraduate information literacy programs: a how-to-do-it manual for librarians. New York: Neal-Schuman Publishers; 1999.

16. Shonrock D, Mulder C. Instruction librarians: Acquiring the proficiencies critical to their work. Coll Res Libr. 1993;54(2):137-49.

17. Peacock J. Teaching skills for teaching librarians: postcards from the edge of the educational paradigm. Aust Acad Res Libr. 2001 [accessed 5 Jan 2009];32(1):26-42. Available from: http://www.alia.org.au/publishing/aarl/32.1/ full.text/jpeacock.html.

18. UBC Health Library Wiki [wiki on Internet]. BOPPPS model [wiki article] [accessed 5 Jan 2009]. Available from: http://hlwiki.slais.ubc.ca/index.php/BOPPPS_Model.

Appendix A begins on the following page. 


\section{Appendix A.}

Table A1. Learning theories chart for health librarians.

\begin{tabular}{|c|c|c|c|}
\hline Theory & Behaviourism & Constructivism/cognitivism & Situated-learning \\
\hline Definition(s) & $\begin{array}{l}\text { "Behaviourists believe learning } \\
\text { takes place when learners are } \\
\text { prompted by a stimulus; good } \\
\text { behaviours are then shaped by } \\
\text { repetition and } \\
\text { reinforcement..." }\end{array}$ & $\begin{array}{l}\text { "Constructivists believe knowledge is not } \\
\text { transmitted but created by learners } \\
\text { themselves...cognitivists believe that a } \\
\text { change in knowledge is constructed by } \\
\text { learners and is stored in the brain for } \\
\text { later retrieval" }\end{array}$ & $\begin{array}{l}\text { "Situated-learning is learning in- } \\
\text { situ in contexts that reflect the } \\
\text { way that knowledge and skills } \\
\text { will eventually be used on the } \\
\text { job; doing and learning 'in } \\
\text { context'..." }\end{array}$ \\
\hline Central tenets & $\begin{array}{l}\text { Learning is shaped by subject } \\
\text { experts; correct behaviours are } \\
\text { rewarded; content must be } \\
\text { mastered by learners }\end{array}$ & $\begin{array}{l}\text { Learning is shaped by individual motiva- } \\
\text { tion and reflection; learner's context, } \\
\text { emotions, experience, and knowledge } \\
\text { are important }\end{array}$ & $\begin{array}{l}\text { Learning is shaped through inter- } \\
\text { action, observation in shared } \\
\text { social, communal contexts; } \\
\text { through sets of shared knowl- } \\
\text { edge objects }\end{array}$ \\
\hline Teacher's role & $\begin{array}{l}\text { "Sage on the stage"; to lecture; } \\
\text { assume power and control; to } \\
\text { reward and punish learners }\end{array}$ & $\begin{array}{l}\text { To facilitate and guide; make learning } \\
\text { relevant; account for different learning } \\
\text { styles and give up control }\end{array}$ & $\begin{array}{l}\text { To facilitate, mentor, guide, } \\
\text { model, lead or follow; assume } \\
\text { power or allow others to } \\
\text { assume }\end{array}$ \\
\hline Learner's role & $\begin{array}{l}\text { To memorize, follow instructions, } \\
\text { obey, master subject content }\end{array}$ & $\begin{array}{l}\text { To collaborate, discuss, debate, question, } \\
\text { listen, participate, reframe, socialize }\end{array}$ & $\begin{array}{l}\text { To engage, interact, listen, } \\
\text { reframe ideas, socialize as part } \\
\text { of team/community }\end{array}$ \\
\hline
\end{tabular}

Table A2. Instructional design example: basic PubMed training session (1.5 h).

\begin{tabular}{|c|c|c|c|c|}
\hline $\begin{array}{l}\text { Learning objectives: } \\
\text { participants will be able to }\end{array}$ & Content heading & Key points to emphasize & $\begin{array}{l}\text { Instructional } \\
\text { techniques }\end{array}$ & $\begin{array}{l}\text { Estimated } \\
\text { time (min) }\end{array}$ \\
\hline Find PubMed.gov & MEDLINE via PubMed & $\begin{array}{l}\text { What is PubMed? } \\
\text { Content, search features, links }\end{array}$ & $\begin{array}{r}\text { Demonstration } \\
\text { Questioning }\end{array}$ & 10 \\
\hline $\begin{array}{l}\text { Do some simple keyword } \\
\text { searching }\end{array}$ & Basic searching & $\begin{array}{l}\text { Keyword searching is similar to } \\
\text { "googling" } \\
\text { Details? How PubMed interprets } \\
\text { keywords and MeSH terms }\end{array}$ & $\begin{array}{l}\text { Demonstration } \\
\text { Trial and error } \\
\text { Group work }\end{array}$ & 20 \\
\hline $\begin{array}{l}\text { Learn how to find best } \\
\text { evidence }\end{array}$ & Clinical questions & $\begin{array}{l}\text { Clinical queries } \\
\text { Systematic reviews } \\
\text { Limits }\end{array}$ & $\begin{array}{l}\text { Demonstration } \\
\text { Discussion } \\
\text { Leave time for "play" }\end{array}$ & 20 \\
\hline $\begin{array}{l}\text { Find fulltext article in } \\
\text { PubMed Central }\end{array}$ & Fulltext linking & $\begin{array}{l}\text { What is PubMed Central? } \\
\text { What are the other links to } \\
\text { fulltext? }\end{array}$ & $\begin{array}{l}\text { Demonstration } \\
\text { Discussion } \\
\text { Shared stories }\end{array}$ & 10 \\
\hline Use other features & $\begin{array}{l}\text { MyNCBI } \\
\text { Bioinformatics }\end{array}$ & Depending on needs & Peer-to-peer sharing & 15 \\
\hline
\end{tabular}


Figure A1. Theory to practice — an early framework for workshop planning (Giustini). (This hybrid framework is derived from Caffarella, Sork, and Young/Harmony.)

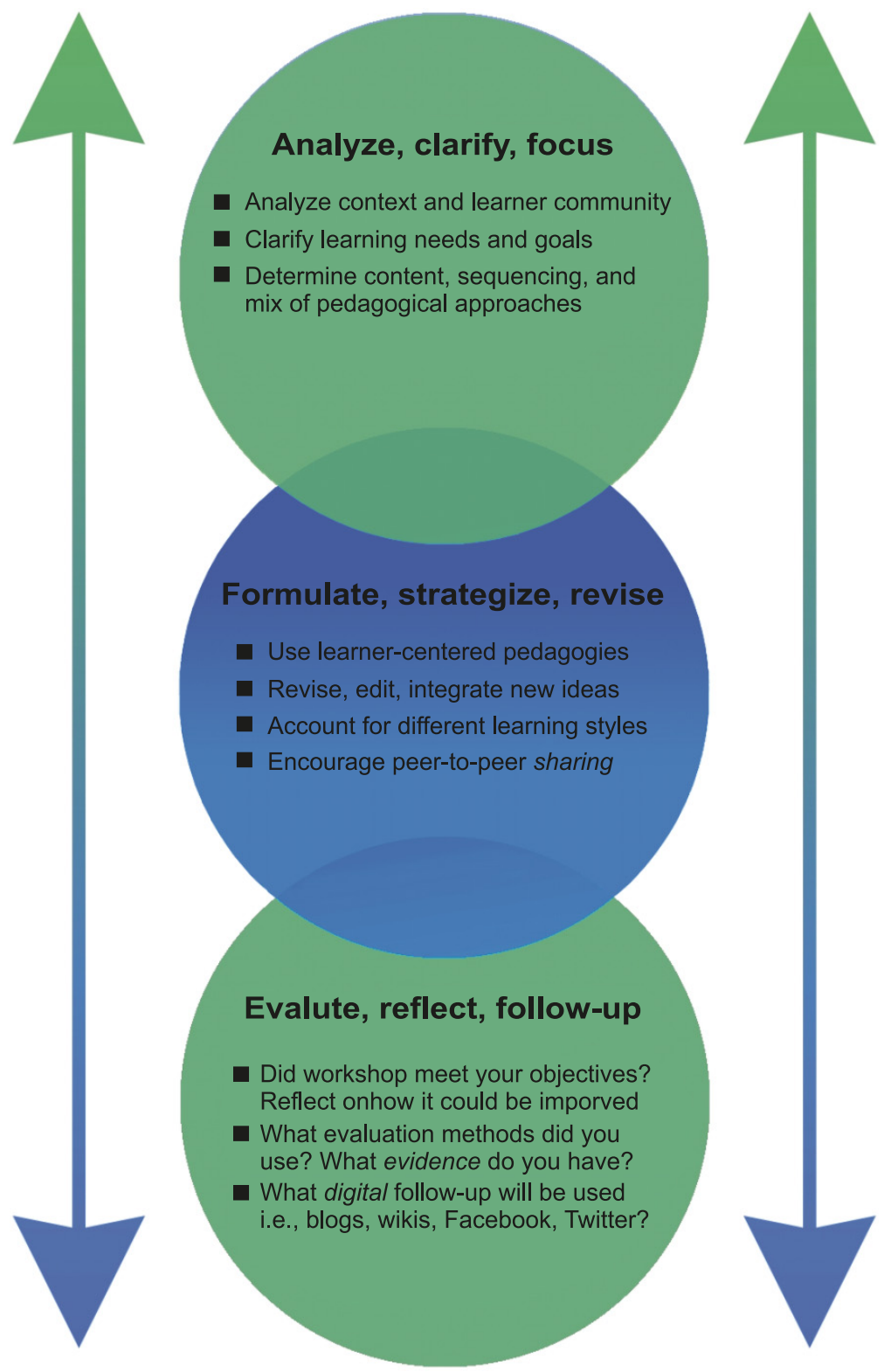


This article has been cited by:

1. 2010. Full Issue in PDF / Numéro complet enform PDF. Journal of the Canadian Health Libraries Association 31:1, 1-24. [Citation] [PDF] [PDF Plus]

2. Dean Giustini. 2010. Evidence-based teaching (EBT) and health librarians: some questions and considerations. Journal of the Canadian Health Libraries Association 31:1, 7-10. [Citation] [PDF] [PDF Plus]

3. Dean Giustini. 2009. Tipping point(s): informal learning for health librarians in an economic downturn. Journal of the Canadian Health Libraries Association 30:3, 113-116. [Citation] [PDF] [PDF Plus] 